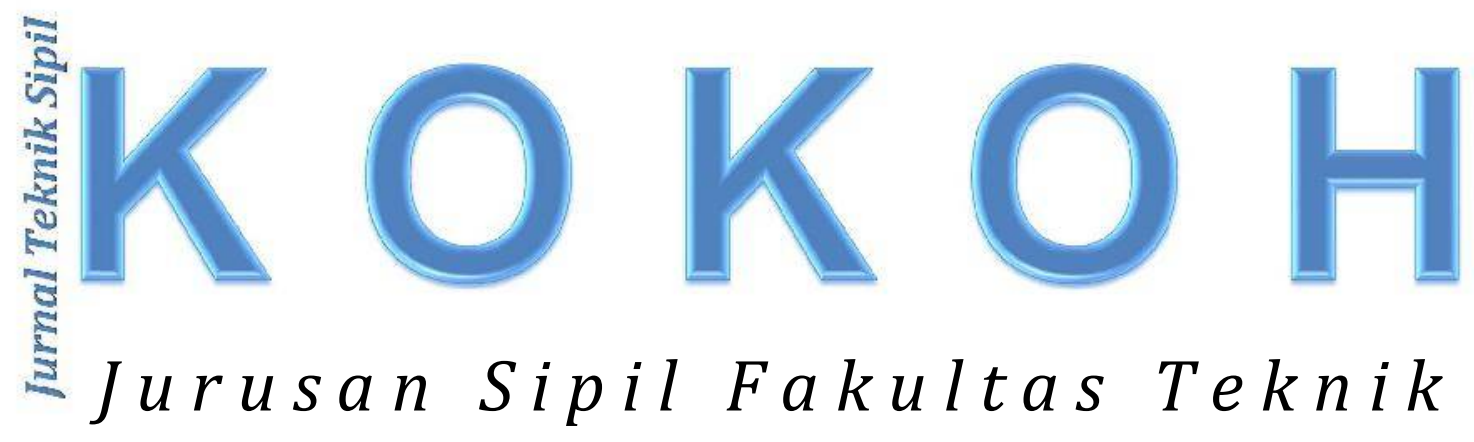

Analisis dan Pemodelan Formasi Pipa Resapan untuk Konservasi Air Tanah pada Lahan Pertanian Irigasi Air Tanah di Kabupaten Takalar

(Darwis Panguriseng)

Pengaruh Tingkat Kebersihan Agregat

Terhadap Kuat Tekan Beton (Tamrin Mallawangeng)

Perilaku Parameter Kuat Geser dan Kuat Tekan Terhadap Tanah yang Distabilisasi dengan Menggunakan Ammonium Chloride (Arman Setiawan)

Pemanfaatan Cangkang Kerang Sebagai Pengganti Parsial Agregat Halus pada Campuran Aspal Beton

(Nur Hadijah Yunianti)

Studi Perilaku Joint Balok Kolom Pracetak dengan Perkuatan Glass Fiber Reinforced Polymer

(Hijriah)

Optimalisasi Variasi Abu Batu dan Pasir untuk Beton Mutu Tinggi (Syahrul Sariman)

Yayasan Andi Sose

Universitas "45" Makassar 


\title{
PERILAKU PARAMETER KUAT GESER DAN KUAT TEKAN \\ TERHADAP TANAH YANG DISTABILISASI DENGAN MENGGUNAKAN AMMONIUM CHLORIDE
}

\author{
Oleh : Arman Setiawan 1), Supardi 2), Wawan Malawat ${ }^{3)}$
}

\begin{abstract}
Stabilization is an effort to modify or develop the properties of existing soil in order to obtain the desired properties. Stabilization method using Ammonium Chloride is used as stabilizing agents, with the aim of changing the physical and mechanical properties of the soil the better. The behavior of the shear strength parameters of the original clay loam soil stabilization and ammonium chloride from the test results of direct shear tests indicate a decline in the value of the friction angle ( $\varnothing)$ on clay soil that has been stabilized, the minimum value of the shear angle $\varnothing=14.20^{\circ}$ obtained at the levels of variation percentage of $5 \%$ ammonium chloride at 28 days curing time. While the value of the maximum shear angle $\varnothing=$ $34.29^{\circ}$ occur in native clay soil without stabilization of ammonium chloride at 3 days curing time. Behavioral parameters on compressive strength and the original clay loam soil stabilization of ammonium chloride uncompressive strength test results (UCS) shows an increasing value of strength (qu) on clay stabilized with ammonium chloride, the highest qu = $1.20 \mathrm{~kg} / \mathrm{cm}^{2}$ with rigid consistency occurs at levels of $5 \%$ the percentage of ammonium chloride with 28 days curing time.
\end{abstract}

\section{Keyword : Stabilization, Ammonium Chloride, Direct Shear and Uncompressive Strength Test}

\section{PENDAHULUAN}

Salah satu persoalan yang muncul dalam dunia konstruksi adalah minimnya lahan tempat membangun yang sesuai dengan spesifikasi teknik, sementara kebutuhan lahan untuk pembangunan terus meningkat. Tidak semua tanah memenuhi syarat sebagai pendukung konstruksi diatasnya, dengan kata lain banyak dijumpai tanah dengan kemampuan daya dukung yang rendah.

1) Dosen Teknik Sipil Universitas 45 Makassar

2) Mahasiswa Teknik Sipil Universitas 45 Makassar

3) Mahasiswa Teknik Sipil Universitas 45 Makassar 
Permasalahan dengan tanah lunak dapat diatasi dengan beberapa metode, seperti menyesuaikan design bangunan dengan kemampuan tanah tempat bangunan didirikan, penggunaan pancang yang dibenamkan hingga menembus kedalaman dan mencapai tanah keras, mendatangkan material tanah lain yang mempunyai karakteristik yang lebih baik untuk mengganti tanah asli hingga kedalaman tertentu, atau dengan metode stabilisasi tanah memodifikasi yang sudah ada untuk memperoleh karakteristik yang lebih baik (meningkatkan daya dukung tanah).

Salah satu alternatif penanganan yang tersedia antara lain dengan menggunakan teknologi stabilisasi tanah. Stabilisasi sendiri merupakan usaha untuk memodifikasi atau mengembangkan sifat-sifat tanah yang ada guna mendapatkan sifat-sifat yang diinginkan.

Metode stabilisasi tanah diantaranya dengan perpaduan atau pencampuran tanah yang bersifat heterogen untuk menghasilkan tanah yang lebih bersifat homogen, penambahan kapur/hydrated lime pada tanah yang mengandung banyak clay, mencampur asphalt dengan tanah, mencampur semen dengan tanah atau dengan menambahkan zat-zat kimia tertentu pada tanah. Stabilisasi dengan menambahkan zat-zat kimia tertentu pada tanah dapat mengubah sifat-sifat kurang menguntungkan dari tanah. Biasanya digunakan untuk tanah yang berbutir halus.

Penambahan zat-zat kimia tertentu pada tanah diantaranya adalah dengan menggunakan metode stabilisasi klorida yang di dasarkan kepada sifat-sifat hidroskopis atau tarikan terhadap air untuk menghasilkan tanah yang lembab serta memperbesar kohesi.

\section{TINJAUAN PUSTAKA}

\subsection{Klasifikasi Tanah}

Sistem klasifikasi tanah memberikan suatu bahasa yang mudah untuk menjelaskan secara singkat sifat-sifat umum tanah yang sangat bervariasi tanpa penjelasan yang terinci. Sebagian besar sistem klasifikasi tanah yang telah dikembangkan untuk tujuan rekayasa didasarkan pada 
sifat-sifat indeks tanah yang sederhana seperti distribusi ukuran butiran dan plastisitas. Dalam artian umum, yang dimaksud dengan tekstur tanah adalah keadaan permukaan tanah yang bersangkutan. Tekstur tanah dipengaruhi oleh ukuran tiap-tiap butir yang ada didalam tanah.

Dalam sistem klasifikasi tanah berdasarkan tekstur, tanah diberi nama atas dasar komponen utama yang dikandungnya, misalnya lempung berpasir (sandy clay), lempung berlanau (silty clay), dan seterusnya.

Gambar 2.1 menunjukkan sistem klasifikasi berdasarkan tekstur tanah yang dikembangkan oleh Departemen Pertanian Amerika (U.S. Department of Agriculture atau USDA).

Sistem ini didasarkan pada ukuran batas dari butiran tanah, yaitu:

a. Pasir : Ukuran butiran antara 2,0-0,05 mm

b. Lanau : Ukuran butiran antara 0,05-0,002 mm

c. Lempung : Ukuran Butiran <0,002 mm

Sehingga presentase partikel berukuran pasir, lanau dan lempung dapat disajikan dengan suatu grafik segitiga.

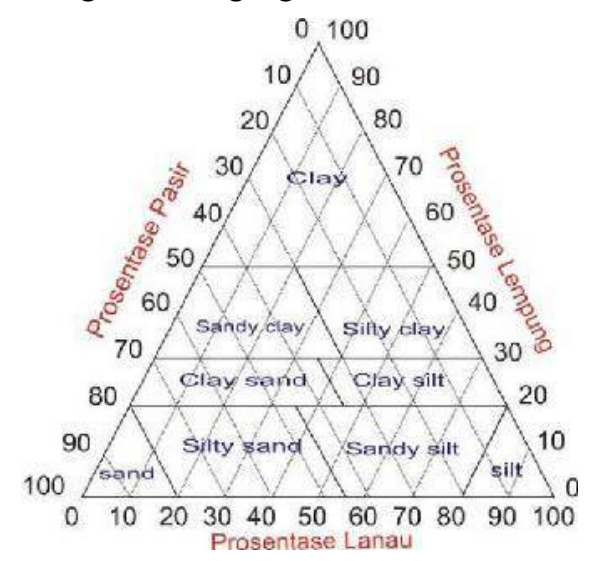

Gambar 2.1. Klasifikasi berdasarkan tekstur oleh USDA

Sistem Klasifikasi Tanah USCS dan Sistem Klasifikasi Tanah AASHTO adalah sistem klasifikasi tanah yang paling sering digunakan pada saat ini. 


\section{A. Sistem Klasifikasi Tanah USCS}

Sistem klasifikasi tanah USCS (Unified Soil Classification System), ini mengelompokkan tanah ke dalam dua kelompok besar sebagai berikut:

1. Tanah berbutir kasar (kerikil dan pasir) bila $>50 \%$ tertahan pada saringan No.200.

2. Tanah berbutir halus (lanau dan lempung) bila $>50 \%$ lolos saringan No. 200.

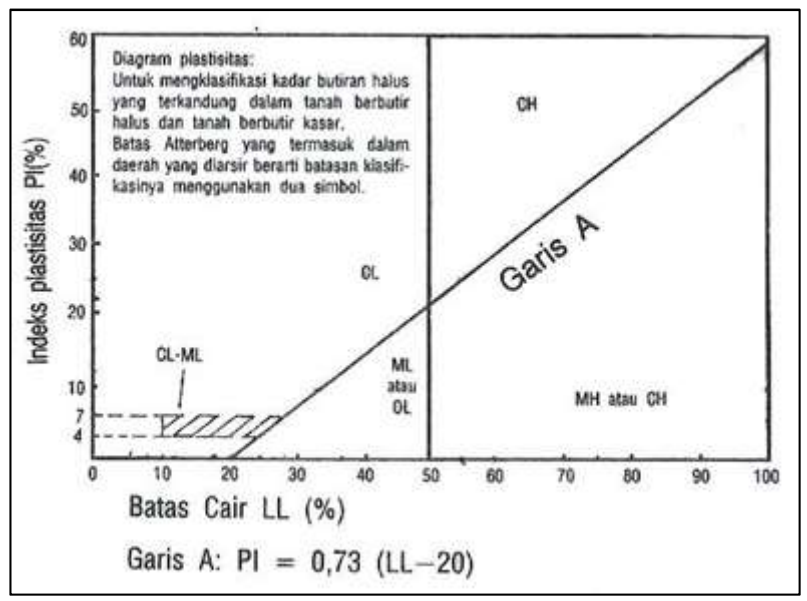

Gambar 2.2. Klasifikasi tanah sistem unified

Simbol-simbol yang digunakan tersebut adalah:

G : kerikil (gravel)

$S:$ pasir (sand)

$\mathrm{C}:$ lempung (clay)

$M$ : Ianau (silt)

$\mathrm{O}$ : lanau atau lempung organic (organic silt or clay)

Pt : tanah gambut dan tanah organik tinggi (peat and highly organic soil)

W : gradasi baik (well-graded)

$P$ : gradasi buruk (poorly graded)

$\mathrm{H}$ : plastisitas tinggi (high-plasticity)

$\mathrm{L}$ : plastisitas rendah (low-plasticity) 


\section{B. Sistem Klasifikasi AASHTO}

Sistem klasifikasi AASHTO (American Association of State Highway and Transportation Officials Classification) membagi tanah kedalam 7 kelompok untuk tanah anorganik yaitu A-1 sampai A-7 dengan jumlah 12 subkelompok. Pengujian yang digunakan hanya analisis saringan dan batas-batas Atterberg. Sistem klasifikasi AASHTO dapat diiihat dalam Tabel 2.1. Tanah-tanah yang diklasifikasikan kedalam kelompok A-1, A-2, dan A-3 adalah tanah-tanah berbutir kasar dimana 35\% atau kurang butirbutir tersebut melalui ayakan No. 200.

Tanah-tanah dimana $35 \%$ atau lebih yang melalui ayakan No. 200 diklasifikasikan dalam kelompok A-4, A-5, A-6, dan A-7. Pada umumnya tanah-tanah ini adalah lumpur dan lempung.

Tabel 2.1. Klasifikasi AASHTO M145-82 Untuk Lapisan Tanah Dasar Jalan Raya

\begin{tabular}{|c|c|c|c|c|c|c|c|c|c|c|c|}
\hline \multirow{4}{*}{$\begin{array}{l}\text { Klasifikasi } \\
\text { Umum }\end{array}$} & \multicolumn{7}{|c|}{ material berbutir } & \multicolumn{4}{|c|}{ Tanah lanau-lempung } \\
\hline & \multicolumn{7}{|c|}{$(<35 \%$ lolos saringan no.200) } & \multicolumn{4}{|c|}{ (>35\% lolos saringan no.200) } \\
\hline & \multicolumn{2}{|c|}{$\mathrm{A}-1$} & \multirow[b]{2}{*}{ A-3 } & \multicolumn{4}{|c|}{ A-2 } & \multirow[b]{2}{*}{ A-4 } & \multirow[b]{2}{*}{$A-5$} & \multirow[b]{2}{*}{ A-6 } & \multirow{2}{*}{\begin{tabular}{|l|} 
A-7 \\
A-7-5 \\
A-7-6 \\
\end{tabular}} \\
\hline & $A-1-a$ & $A-1-b$ & & A-2-4 & A-2-5 & $\begin{array}{c}\text { A-2-- } \\
6\end{array}$ & A-2-7 & & & & \\
\hline $\begin{array}{l}\text { Analisis } \\
\text { ayakan } \\
\text { (\% lolos) } \\
\text { No. } 10 \\
\text { No. } 40 \\
\text { No. } 200\end{array}$ & $\begin{array}{c}50 \\
\text { maks } \\
30 \\
\text { maks } \\
15 \\
\text { maks }\end{array}$ & $\begin{array}{c}----- \\
50 \\
\text { maks } \\
25 \\
\text { maks }\end{array}$ & $\begin{array}{c}---- \\
51 \\
\text { maks } \\
10 \\
\text { maks }\end{array}$ & $\begin{array}{c}- \\
-- \\
- \\
- \\
35 \\
\text { maks }\end{array}$ & $\begin{array}{c}- \\
---- \\
- \\
- \\
35 \\
\text { maks }\end{array}$ & $\begin{array}{c}- \\
-- \\
-- \\
- \\
35 \\
\text { maks }\end{array}$ & $\begin{array}{c}- \\
--- \\
- \\
- \\
35 \\
\text { maks }\end{array}$ & $\begin{array}{l}36 \\
\text { min }\end{array}$ & 36 min & $36 \mathrm{~min}$ & $36 \mathrm{~min}$ \\
\hline \multicolumn{12}{|l|}{$\begin{array}{l}\text { Sifat Fraksi } \\
\text { yang lewat: } \\
\text { \# No.40 }\end{array}$} \\
\hline $\begin{array}{c}\text { Batas Cair } \\
\text { (LL) }\end{array}$ & \multicolumn{2}{|c|}{-ב- } & ------ & $\begin{array}{c}40 \\
\text { maks }\end{array}$ & $\begin{array}{c}41 \\
\min \end{array}$ & $\begin{array}{c}40 \\
\text { Maks }\end{array}$ & $\begin{array}{c}41 \\
\min \end{array}$ & $\begin{array}{c}40 \\
\max \end{array}$ & $40 \min$ & $\begin{array}{c}40 \\
\max \end{array}$ & $41 \mathrm{~min}$ \\
\hline $\begin{array}{c}\text { Indeks } \\
\text { Plastisitas }\end{array}$ & \multicolumn{2}{|c|}{6 maks } & N.P & $\begin{array}{c}10 \\
\text { maks }\end{array}$ & $\begin{array}{c}10 \\
\text { maks }\end{array}$ & $\begin{array}{c}11 \\
\min \end{array}$ & $\begin{array}{c}11 \\
\min \end{array}$ & $\begin{array}{c}10 \\
\max \end{array}$ & $\begin{array}{c}10 \\
\max \end{array}$ & $11 \min$ & $12 \mathrm{~min}$ \\
\hline $\begin{array}{l}\text { Indeks } \\
\text { kelompok } \\
\qquad(\mathrm{GI}\end{array}$ & \multicolumn{2}{|c|}{0} & 0 & \multicolumn{2}{|c|}{0 maks } & \multicolumn{2}{|c|}{4 maks } & $\begin{array}{c}8 \\
\text { maks }\end{array}$ & $\begin{array}{c}12 \\
\text { maks }\end{array}$ & $\begin{array}{c}16 \\
\text { maks }\end{array}$ & $\begin{array}{c}20 \\
\text { maks }\end{array}$ \\
\hline Jenis Umum & \multicolumn{2}{|c|}{$\begin{array}{c}\text { Fragmen } \\
\text { batuan } \\
\text { Kerikil dan pasir }\end{array}$} & $\begin{array}{l}\text { Pasir } \\
\text { halus }\end{array}$ & \multicolumn{4}{|c|}{$\begin{array}{c}\text { Kerikil atau pasir lanauan atau } \\
\text { lempung }\end{array}$} & \multicolumn{2}{|c|}{ Tanah lanau } & \multicolumn{2}{|c|}{$\begin{array}{l}\text { Tanah } \\
\text { lempung }\end{array}$} \\
\hline $\begin{array}{l}\text { Tingkat } \\
\text { umum } \\
\text { sebagai } \\
\text { Tanah } \\
\text { dasar }\end{array}$ & \multicolumn{7}{|c|}{ Sangat baik sampai baik } & \multicolumn{4}{|c|}{ Cukup baik sampai buruk } \\
\hline
\end{tabular}

Catatan : Kelompok A-7 dibagi atas A-7-5 dan A-7-6 bergantung pada batas plastisnya (PL)

Untuk PL>30 klasifikasinya A-7-5

Untuk PL $<30$ klasifikasinya A-7-6

$\mathrm{np}=$ non plastis 
Indeks kelompok (group indeks) digunakan untuk mengetahui lebih lanjut tanah-tanah dalam kelompoknya. Indeks kelompok dihitung dengan persamaan (Braja M.Das, 1991):

$$
\mathrm{GI}=(\mathrm{F}-35)((0.2+0.005(\mathrm{LL}-40))+0.01(\mathrm{~F}-15)(\mathrm{PI}-10)
$$

Dengan :

$$
\begin{aligned}
& \mathrm{GI}=\text { Indeks kelompok } \\
& \mathrm{LL}=\text { Batas cair } \\
& \mathrm{F}=\text { Persen material lolos saringan no. } 200 \\
& \mathrm{PI}=\text { Indeks plastisitas }
\end{aligned}
$$

Bila nilai indeks keiompok (GI) semakin tinggi, semakin berkurang ketepatan penggunaan tanahnya. Tanah granuler diklasifikasikan ke dalam klasifikasi A-1 sampai A-3. Tanah A-1 granuler yang bergradasi baik, sedang A3 adalah pasir yang bergradasi buruk. Tanah A-2 termasuk tanah granuler (kurang dari 35\% lolos saringan No. 200), tetapi masih terdiri atas lanau dan lempung. Tanah berbutir halus diklasifikasikan dari A-4 sampai A-7, yaitu tanah lempung lanau. Perbedaan keduanya didasarkan pada batas-batas atterberg.

\subsection{Tanah Lunak}

Tanah lunak atau tanah lempung merupakan agregat partikelpartikel berukuran mikroskopik dan submikroskopik yang berasal dari pembusukan kimiawi unsur-unsur penyusun batuan, dan bersifat plastis dalam selang kadar air sedang sampai luas. Dalam keadaan kering sangat keras, dan tak mudah terkelupas hanya dengan jari tangan. Permeabilitas lempung sangat rendah (Terzaghi dan Peck, 1987).

Pelapukan kimiawi menghasilkan pembentukan kelompok-kelompok partikel yang berukuran koloid $(<0,002 \mathrm{~mm})$ yang dikenal sebagi mineral lempung.

Sifat yang khas dari tanah lempung adalah dalam keadaan kering dia akan bersifat keras, dan jika basah akan bersifat lunak plastis, dan kohesif, mengembang dan menyusut dengan cepat, sehingga mempunyai 
perubahan volume yang besar dan itu terjadi karena pengaruh air. Lempung merupakan tanah berbutir halus koloidal yang tersusun dari mineral - mineral yang dapat mengembang.

Lempung ekspansif memiliki sifat khusus yaitu kapasitas pertukaran ion yang tinggi yang akan mengakibatkan lempung jenis ini memiliki potensi pengembangan yang cukup tinggi apabila terjadi perubahan kadar air. Jika kadar air bertambah, tanah lempung ekspansif akan mengembang disertai dengan kenaikan tekanan air pori dan tekanan pengembangannya. Sebaliknya, jika kadar air turun sampai dengan batas susutnya, lempung ekspansif akan mengalami penyusutan yang cukup tinggi.

\subsection{Stabilisasi Tanah}

Stabilisasi tanah disebut dengan perbaikan tanah dibidang rekayasa teknik sipil. Stabilisasi dapat dilaksanakan dengan menambah sesuatu bahan atau komposit tertentu untuk menambah kekuatan pada tanah.

Menurut Bowles (1986) stabilisasi tanah dapat berupa:

1. meningkatkan kerapatan tanah,

2. menambah material yang tidak aktif sehingga meningkatkan kohesi dan/atau tahan gesek yang timbul,

3. menambah material untuk menyebabkan perubahan-perubahan kimiawi dan fisik dari material tanah,

4. menurunkan muka air tanah,

5. mengganti tanah yang buruk.

Pertambahan daya dukung tanah dapat dicapai dengan mengubah sifat-sifat tanah dari sudut geser tanah $(\varphi)$, kohesi (c) dan berat satuannya (Y). Penurunan dapat direduksi dengan menambahkan kerapatan rongga dari pemampatan partikel tanah. (Wesley L.D. 1977)

Stabilisasi tanah dengan ammonium chloride diartikan sebagai pencampuran antara tanah yang telah dihancurkan, ammonium chloride 
dan air, yang kemudian dipadatkan sehingga menghasilkan suatu kondisi tanah yang berbeda dari sebelumnya.

Stabilisasi klorida biasanya didasarkan kepada sifat-sifat hidroskopis (tarikan terhadap air) dari material ini untuk menghasilkan tanah yang lembab yang memperbesar kohesi. (J.E. Bowles, 1986)

\subsection{Kuat Geser}

Kekuatan geser suatu massa tanah merupakan perlawanan internal tanah tersebut per satuan luas terhadap keruntuhan atau pergeseran sepanjang bidang geser dalam tanah yang dimaksud. Untuk menganalisis masalah stabilitas tanah seperti daya dukung, stabilitas talud (lereng), tekanan tanah kesamping pada turap maupun tembok penahan tanah, mula-mula kita harus mengetahui sifat-sifat ketahanan penggeserannya tanah tersebut. Kuat geser tanah adalah gaya perlawanan yang dilakukan oleh butir-butir tanah terhadap desakan atau tarikan. Kekuatan geser tanah ditentukan untuk mengukur kemampuan tanah menahan tekanan tanpa terjadi keruntuhan. Oleh karena itu, apabila tanah mengalami pembebanan akan ditahan oleh:

1. Kohesi tanah yang bergantung pada jenis tanah dan kepadatannya.

2. Gesekan antara butir-butir tanah yang besarnya berbanding lurus dengan tegangan normal pada bidang gesernya.

Tanah pada umumnya digolongkan sebagai berikut:

1. Tanah berkohesi atau berbutir halus (misalnya lempung)

2. Tanah tidak berkohesi atau berbutir kasar (misalnya pasir)

3. Tanah berkohesi-gesekan, ada c dan $\emptyset$ (misalnya lanau)

Teori untuk menentukan kekuatan geser tanah yang umum dipakai adalah metode Mohr-Coulomb. Mohr dan Coulomb menyatakan bahwa kekuatan geser tanah $(\mathrm{T})$ merupakan fungsi dari kohesi dan sudut geserdalam tanah.

Kekuatan geser tanah dapat ditentukan sebagai berikut:

$$
\tau=\mathrm{c}+\sigma \tan \emptyset
$$




\section{Dimana:}

$\tau$ : kekuatan geser tanah

c : kohesi tanah

$\varnothing$ : sudut geser-dalam

$\sigma$ : tegangan normal pada bilangan kritis

Hubungan persamaan ini digambarkan sebagai berikut:

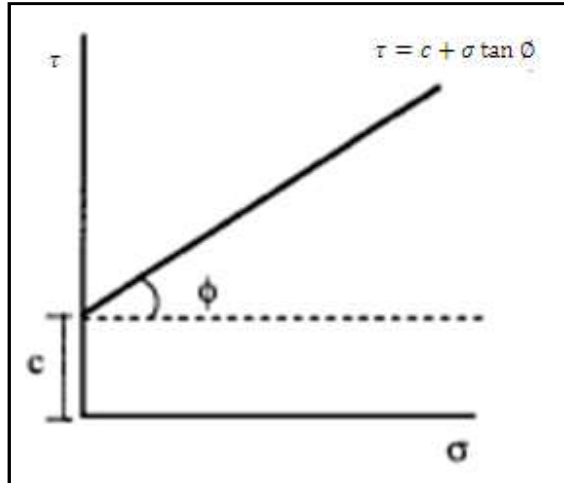

Gambar 2.3. Persamaan Coulomb (Sunggono, 1984)

Parameter kuat geser tanah ditentukan dari pengujian-pengujian laboratorium pada benda uji yang diambil dari lokasi lapangan hasil pengeboran yang dianggap mewakili (Hary Christady).

Penentuan parameter kuat geser dapat ditentukan melalui pengujian Direct Shear atau geser langsung. Kekuatan tanah yang diperoleh dari percobaan geser langsung adalah dalam kondisi drained, karena air dalam pori tanah diijinkan keluar selama pembebanan.

\subsection{Kuat Tekan}

Pengujian kekuatan tekan bebas untuk menentukan besarnya kekuatan tekan bebas contoh tanah dan batuan yang bersifat kohesif dalam keadaan asli maupun buatan.Yang dimaksud dengan kekuatan tekan bebas ialah besarnya beban aksial persatuan luas pada saat benda uji mengalami keruntuhan atau pada saat regangan aksial mencapai $20 \%$. Nilai kuat tekan bebas (qu) untuk setiap benda uji dihitung dengan menggunankan rumus: 
1. Regangan axial $(\varepsilon)$

$$
\varepsilon=\frac{\Delta L}{L_{0}}
$$

$$
\begin{aligned}
& \text { Dimana : } \Delta \mathrm{L}=\text { Perubahan Panjang } \\
& \mathrm{L}_{0}=\text { Panjang Contoh tanah }
\end{aligned}
$$

2. Luas Penampang rata - rata $(A)$

$$
A=\frac{A_{0}}{1-\varepsilon}
$$

$$
\begin{array}{rlll}
\text { Dimana : } \quad A_{0} & = & \text { Luas Penampang awal } \\
\mathrm{A} & = & \text { Luas Penampang koreksi }\left(\mathrm{cm}^{2}\right)
\end{array}
$$

3. Kuat tekan tanah (qu)

$$
q u=\frac{(R \cdot L R C)}{A}
$$

Dimana :

$\mathrm{R} \quad=$ Pembacaan beban (divisi)

LRC = Koefisien beban Ring/Load Ribg Koefisien (Kg/div)

A $=$ Luas Penampang korelasi $\left(\mathrm{cm}^{2}\right)$

\subsection{Ammonium Chloride}

Amines quaternary ammonium salts merupakan bagian terbesar dari bahan kimia organik. Quaternary ammonium salts sering disebut sebagai bagian organik dari garam ammonium.

Jika atom hydrogen dari ammonium chloride $(\mathrm{NH} 4 \mathrm{Cl})$ diganti dengan grup organik maka terbentuklah quaternary ammonium salts. Formula dari quaternary ammonium chloride adalah sebagai berikut:

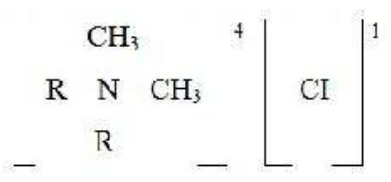

Sebagai senyawa utama amines akan bereaksi dengan asam chloride untuk membentuk garam yang larut dalam air. Quaternary ammonium chloride dapat larut dengan mudah dalam air sampai dengan konsentrasi $8 \%$ dari berat air. 


\section{METODOLOGI PENELITIAN}

\subsection{Diagram Alir Penelitian}

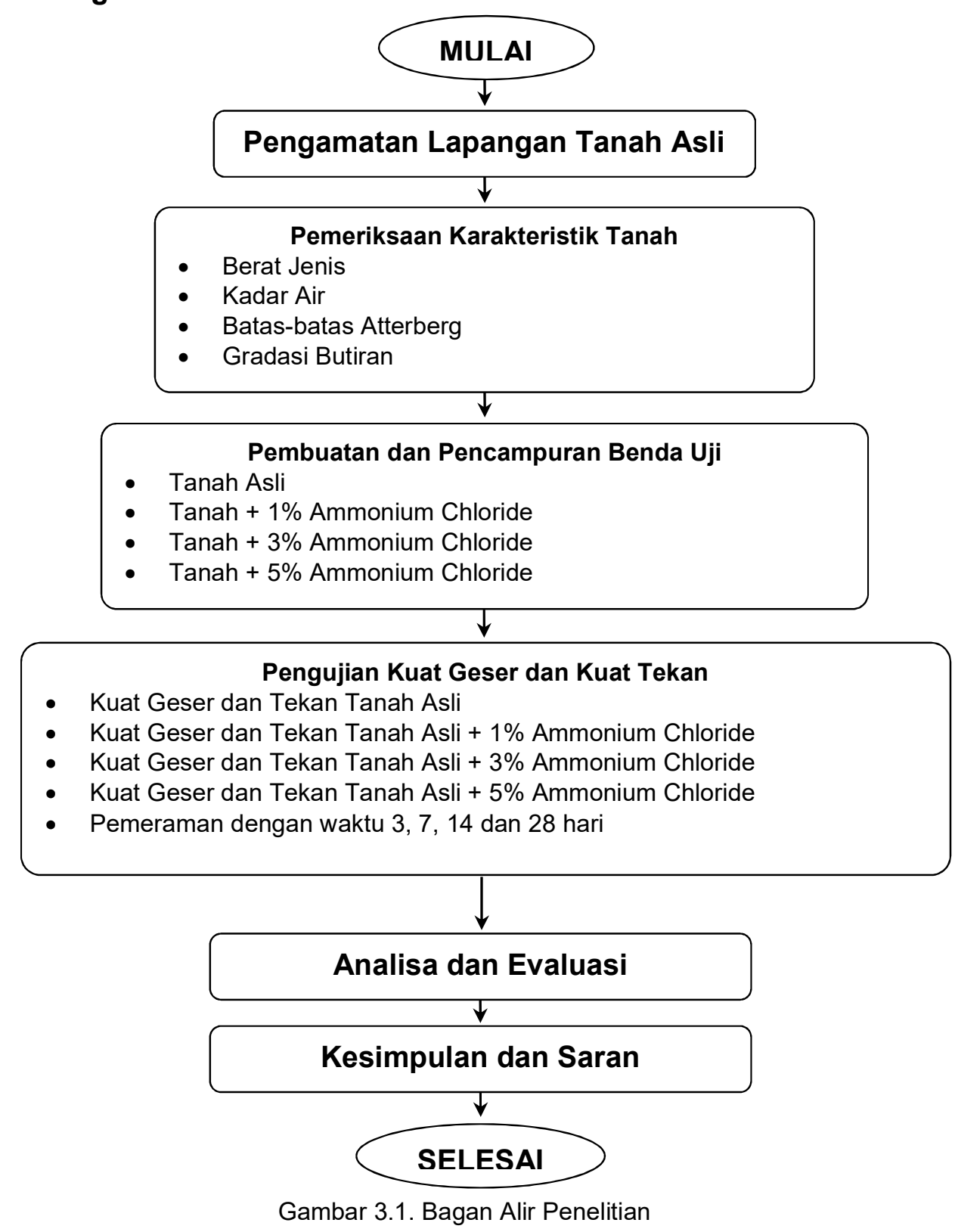

\subsection{Variasi Campuran dan Jumlah Benda Uji}

Dalam penelitian ini sampel uji terdiri dari material tanah asli dan campuran yang dibuat dengan variasi penambahan Ammonium Cloride dalam jumlah tertentu, yaitu berdasarkan prosentase perbandingan berat 
Ammonium Cloride dengan tanah lempung. Dari ketiga variasi campuran pada sampel tanah, akan kami analisa pengaruh Ammonium Cloride terhadap perbaikan tanah dasar.

Variasi campuran dan jumlah sampel dalam setiap pengujian dapat dilihat pada tabel dibawah ini

Tabel 3.1. Jumlah Sampel Kuat Tekan dan Geser

\begin{tabular}{|c|c|c|c|c|c|}
\hline No & Jenis Percobaan & Komposisi Campuran & \begin{tabular}{|c|} 
Kode \\
Sampel
\end{tabular} & \begin{tabular}{|l|} 
Jumlah \\
Sampel \\
\end{tabular} & $\begin{array}{c}\text { Total } \\
\text { Sampel }\end{array}$ \\
\hline \multirow[t]{4}{*}{2} & \multirow{4}{*}{$\begin{array}{l}\text { Kuat Tekan } \\
\text { Bebas (UCST) }\end{array}$} & Tanah Asli & KT0 & 2 & \multirow{4}{*}{8} \\
\hline & & Tanah + 1\% Ammonium Chloride & KT1 & 2 & \\
\hline & & Tanah + 3\% Ammonium Chloride & KT2 & 2 & \\
\hline & & Tanah + 5\% Ammonium Chloride & KT3 & 2 & \\
\hline \multirow[t]{4}{*}{3} & \multirow{4}{*}{$\begin{array}{l}\text { Kuat Tekan } \\
\text { Bebas (UCST) }\end{array}$} & Tanah Asli & KTP0 & 8 & \multirow{4}{*}{32} \\
\hline & & Tanah + 1\% Ammonium Chloride & KTP1 & 8 & \\
\hline & & Tanah + 3\% Ammonium Chloride & KTP2 & 8 & \\
\hline & & Tanah + 5\% Ammonium Chloride & KTP3 & 8 & \\
\hline \multirow[t]{4}{*}{4} & \multirow{4}{*}{$\begin{array}{l}\text { Geser Langsung } \\
\text { (Direct Shear) }\end{array}$} & Tanah Asli & GLO & 3 & \multirow{4}{*}{12} \\
\hline & & Tanah + 1\% Ammonium Chloride & GL1 & 3 & \\
\hline & & Tanah + 3\% Ammonium Chloride & GL2 & 3 & \\
\hline & & Tanah + 5\% Ammonium Chloride & GL3 & 3 & \\
\hline \multirow[t]{4}{*}{5} & \multirow{4}{*}{$\begin{array}{l}\text { Geser Langsung } \\
\text { (Direct Shear) }\end{array}$} & Tanah Asli & GLP0 & 8 & \multirow{4}{*}{32} \\
\hline & & Tanah + 1\% Ammonium Chloride & GLP1 & 8 & \\
\hline & & Tanah + 3\% Ammonium Chloride & GLP2 & 8 & \\
\hline & & Tanah + 5\% Ammonium Chloride & GLP3 & 8 & \\
\hline \multicolumn{5}{|c|}{ Total Benda Uji } & 84 \\
\hline
\end{tabular}

(Hasil Perhitungan)

Dalam penentuan jumlah material Ammonium Chlorida yang digunakan dapat dihitung dengan cara sebagai berikut:

Untuk Berat tanah $=2000$ gram, variasi campuran $5 \%$ Ammonium Cloride dari berat tanah maka $2000 \times 0.05=100$ gram. Jumlah bahan Ammonium Chlorida untuk masing-masing variasi campuran dapat dilihat pada tabel berikut: 
Tabel 3.2. Variasi Campuran Ammonium Chloride

\begin{tabular}{|c|c|c|c|c|}
\hline Jenis Percobaan & Komposisi Campuran & $\begin{array}{c}\text { Kode } \\
\text { Sampel }\end{array}$ & $\begin{array}{c}\text { Tanah } \\
(\text { gram })\end{array}$ & $\begin{array}{c}\text { Ammonium } \\
\text { Chloride } \\
\text { (gram) }\end{array}$ \\
\hline \multirow{4}{*}{$\begin{array}{l}\text { Kuat Tekan Bebas } \\
\text { (UCST) }\end{array}$} & Tanah Asli & KT0 & 320 & 0 \\
\hline & Tanah + 1\% Ammonium Chloride & KT1 & 316.80 & 3.2 \\
\hline & Tanah + 3\% Ammonium Chloride & KT2 & 310.40 & 9.6 \\
\hline & Tanah + 5\% Ammonium Chloride & KT3 & 304.00 & 16 \\
\hline \multirow{4}{*}{$\begin{array}{l}\text { Kuat Tekan Bebas } \\
\text { (UCST) }\end{array}$} & Tanah Asli & KTP0 & 320 & 0 \\
\hline & Tanah + 1\% Ammonium Chloride & KTP1 & 316.80 & 3.2 \\
\hline & Tanah + 3\% Ammonium Chloride & KTP2 & 310.40 & 9.6 \\
\hline & Tanah + 5\% Ammonium Chloride & KTP3 & 304.00 & 16 \\
\hline \multirow{4}{*}{$\begin{array}{l}\text { Geser Langsung } \\
\text { (Direct Shear) }\end{array}$} & Tanah Asli & GL0 & 98 & 0 \\
\hline & Tanah + 1\% Ammonium Chloride & GL1 & 97.02 & 0.98 \\
\hline & Tanah + 3\% Ammonium Chloride & GL2 & 95.06 & 2.94 \\
\hline & Tanah + 5\% Ammonium Chloride & GL3 & 93.10 & 4.9 \\
\hline \multirow{4}{*}{$\begin{array}{l}\text { Geser Langsung } \\
\text { (Direct Shear) }\end{array}$} & Tanah Asli & GLP0 & 98 & 0 \\
\hline & Tanah + 1\% Ammonium Chloride & GLP1 & 97.02 & 0.98 \\
\hline & Tanah + 3\% Ammonium Chloride & GLP2 & 95.06 & 2.94 \\
\hline & Tanah + 5\% Ammonium Chloride & GLP3 & 93.10 & 4.9 \\
\hline
\end{tabular}

(Hasil Perhitungan)

\subsection{Metode Analisis}

Pada analisa data yang digunakan yaitu analisis terhadap data hasil uji di laboratorium dengan langkah-langkah sebagai berikut ini.

1. Analisis kadar air dan berat jenis tanah lempung.

2. Analisis distribusi butiran terhadap tanah yaitu melakukan analisis hasil pengujian tanah di laboratorium dan klasifikasinya menurut klasifikasi tanah serta menggolongkannya menurut jenis mineral tanah.

3. Analisis batas-batas Atterberg untuk menklasifikasikan hasil uji batas cair dan batas plastis golongan tanah lempung.

4. Analisis hasil kuat tekan bebas dimaksudkan untuk mengetahui kekuatan tekan bebas tanah kohesif dalam keadaan asli maupun keadaan buatan.

5. Analisis hasil geser langsung untuk mengetahui nilai kohesi (c ) dan nilai sudut geser dalam $(\varnothing)$ variasi campuran Ammonium Cloride 
terhadap peningkatan daya dukung tanah. Analisis ini digunakan untuk mencari hubungan penambahan Ammonium Cloride yang dituangkan dalam grafik serta analisa mengenai tanah yang diberi bahan stabilisasi Ammonium.

6. Analisa hasil uji Kuat Tekan Bebas dengan Pemeraman digunakan untuk perbandingan antara nilai qu Tanah asli, nilai qu tanpa rendaman dan Nilai qu pemeraman.

7. Analisa hasil uji Geser Langsung dengan pemeraman digunakan untuk perbandingan antara nilai kohesi dan nilai sudut geser dalam Tanah asli, nilai kohesi dan nilai sudut geser dalam tanpa rendaman dan Nilai kohesi dan nilai sudut geser dalam pemeraman.

\section{HASIL PENELITIAN DAN PEMBAHASAN}

\subsection{Karakteristik Fisis Tanah Penelitian}

Tabel 4.1. Rekapitulasi Hasil Pemeriksaan Karakteristik Tanah

\begin{tabular}{|c|c|}
\hline Jenis Pemeriksaan & Hasil pemeriksaan \\
\hline 1. Kadar air asli & $25,25 \%$ \\
\hline 2. Berat Jenis Spesifik & 2.545 \\
\hline 3. Gradasi butiran & $\begin{array}{ll}\text { Pasir } & =48.69 \% \\
\text { Lanau } & =9.2 \% \\
\text { Lempung } & =42.11 \%\end{array}$ \\
\hline 4. Batas-Batas Atterberg & $\begin{array}{ll}\text { Batas Cair }(\mathrm{LL}) & =44,30 \% \\
\text { Batas Plastis }(\mathrm{PL}) & =25,36 \% \\
\text { Batas Susut }(\mathrm{SL}) & =19.02 \%\end{array}$ \\
\hline 5. Klasifikasi Tanah & $\begin{array}{l}\text { USDA } \rightarrow \text { Lempung Berpasir } \\
\text { USCS } \rightarrow \text { CL (termasuk dalam klasifikasi tanah } \\
\text { lempung berpasir dengan plastisitas rendah) } \\
\text { AASHTO } \rightarrow \text { A-7-6 (Tanah berlempung) }\end{array}$ \\
\hline
\end{tabular}

(Hasil Pemeriksaan Laboratorium) 


\subsection{Perilaku Parameter Kuat Geser}

Tabel 4.2. Nilai Sudut Geser Variasi Ammonium Chloride

\begin{tabular}{|c|c|c|c|c|c|}
\hline \multirow{2}{*}{ No } & \multirow{2}{*}{$\begin{array}{c}\text { Variasi } \\
\text { Ammonium } \\
\text { Chloride (\%) }\end{array}$} & \multicolumn{4}{|c|}{ Nilai Susut Geser $\left({ }^{\circ}\right)$} \\
\cline { 3 - 6 } & peram 3 hari & $\begin{array}{c}\text { Sampel } \\
\text { peram 7 hari }\end{array}$ & $\begin{array}{c}\text { Sampel } \\
\text { peram 14 hari }\end{array}$ & $\begin{array}{c}\text { Sampel } \\
\text { peram 28 hari }\end{array}$ \\
\hline 1 & 0 & 34.29 & 28.63 & 21.31 & 17.33 \\
\hline 2 & 1 & 33.54 & 26.89 & 20.30 & 16.28 \\
\hline 3 & 3 & 31.96 & 25.08 & 19.34 & 15.27 \\
\hline 4 & 5 & 30.33 & 24.13 & 18.31 & 14.20 \\
\hline
\end{tabular}

(Hasil Pemeriksaan Laboratorium)

Dari Gambar grafik 4.1. menunjukkan penambahan kadar ammonium chloride dan lamannya pemeraman (curing time) dapat menurunkan nilai sudut geser.

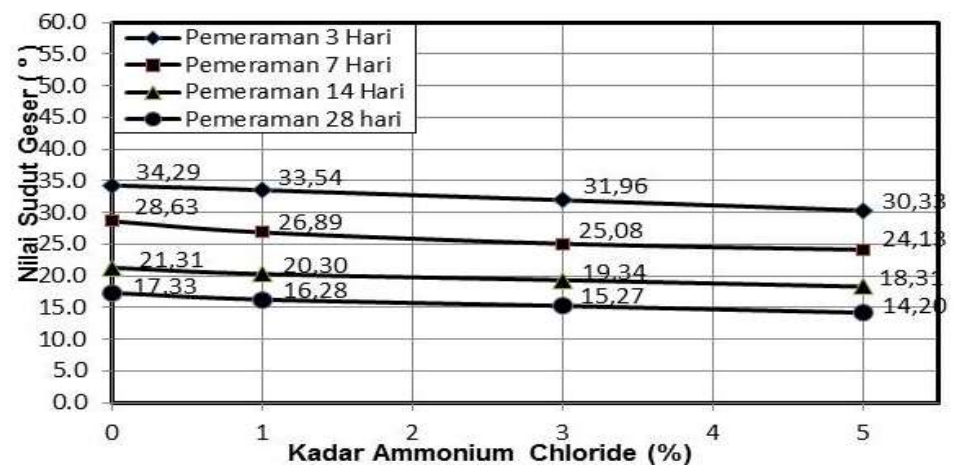

Gambar 4.1. Grafik Hubungan Nilai Sudut Geser dan Kadar Ammonium Chloride

Terlihat bahwa perubahan pada tiap-tiap persentase kadar ammonium chloride dan lamanya waktu pemeraman (curing time) memberi nilai sudut geser $(\varnothing)$ yang cenderung menurun .

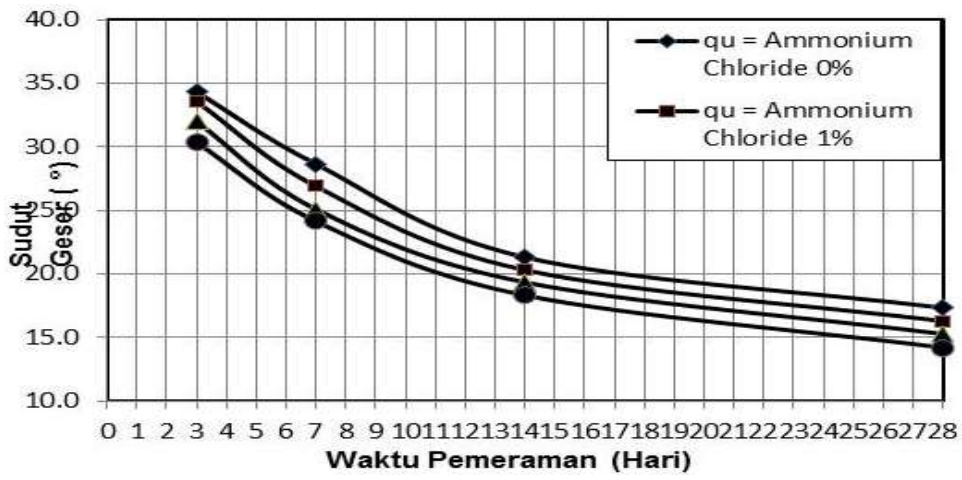

Gambar 4.2. Grafik Hubungan Sudut Geser dan Waktu Pemeraman 
Dari Gambar grafik 4.2. memperlihatkan hubungan antara nilai sudut geser dengan waktu pemeraman tanah yang telah distabilisasi dengan ammonium chloride. Pengaruhnya terhadap sudut geser minimum berada pada kadar persentae ammonium chloride $5 \%$ antara waktu 3, 7, 14 , dan 28 hari yang signifikan. Hasil pengujian sudut geser $(\varnothing)$ terhadap waktu pemeraman dengan variasi kadar ammonium chloride menunjukkan bahwa nilai sudut geser minimum $\varnothing=14,20^{\circ}$, terjadi pada variasi kadar persentase ammonium chloride $5 \%$ dengan waktu curing 28 hari.

\subsection{Perilaku Parameter Kuat Tekan Bebas}

Tabel 4.3. Hasil Pengujian Kuat Tekan Bebas

\begin{tabular}{|c|c|c|c|c|}
\hline \multirow{2}{*}{$\begin{array}{l}\text { Curing } \\
\text { (hari) }\end{array}$} & \multirow{2}{*}{$\begin{array}{l}\text { Komposisi } \\
\text { Campuran }\end{array}$} & \multicolumn{2}{|c|}{ Nilai qu $\left(\mathrm{kg} / \mathrm{cm}^{2}\right)$} & \multirow{2}{*}{$\begin{array}{c}\text { qu rata-rata } \\
\left(\mathrm{kg} / \mathrm{cm}^{2}\right)\end{array}$} \\
\hline & & Sampel 1 & Sampel 2 & \\
\hline \multirow{4}{*}{3} & Tanah Asli & 0.20 & 0.18 & 0.19 \\
\hline & $\mathrm{Tnh}+\mathrm{AC} 1 \%$ & 0.24 & 0.23 & 0.24 \\
\hline & Tnh + AC 3\% & 0.27 & 0.29 & 0.28 \\
\hline & Tnh + AC 5\% & 0.33 & 0.35 & 0.34 \\
\hline \multirow{4}{*}{7} & Tanah Asli & 0.24 & 0.26 & 0.25 \\
\hline & Tnh + AC 1\% & 0.30 & 0.27 & 0.29 \\
\hline & Tnh + AC 3\% & 0.36 & 0.41 & 0.39 \\
\hline & Tnh + AC 5\% & 0.43 & 0.51 & 0.47 \\
\hline \multirow{4}{*}{14} & Tanah Asli & 0.52 & 0.57 & 0.55 \\
\hline & $\mathrm{Tnh}+\mathrm{AC} 1 \%$ & 0.59 & 0.63 & 0.61 \\
\hline & Tnh + AC 3\% & 0.64 & 0.72 & 0.68 \\
\hline & Tnh + AC 5\% & 0.72 & 0.79 & 0.76 \\
\hline \multirow{4}{*}{28} & Tanah Asli & 0.59 & 0.68 & 0.63 \\
\hline & $\mathrm{Tnh}+\mathrm{AC} 1 \%$ & 0.72 & 0.83 & 0.77 \\
\hline & Tnh + AC 3\% & 1.01 & 1.15 & 1.08 \\
\hline & Tnh + AC 5\% & 1.15 & 1.25 & 1.20 \\
\hline
\end{tabular}

(Hasil Pemeriksaan Laboratorium)

Untuk hubungan Nilai qu dan Variasi Kadar Ammonium Chloride dengan pemeraman dapat dilihat pada Gambar 4.3 sebagai berikut. 


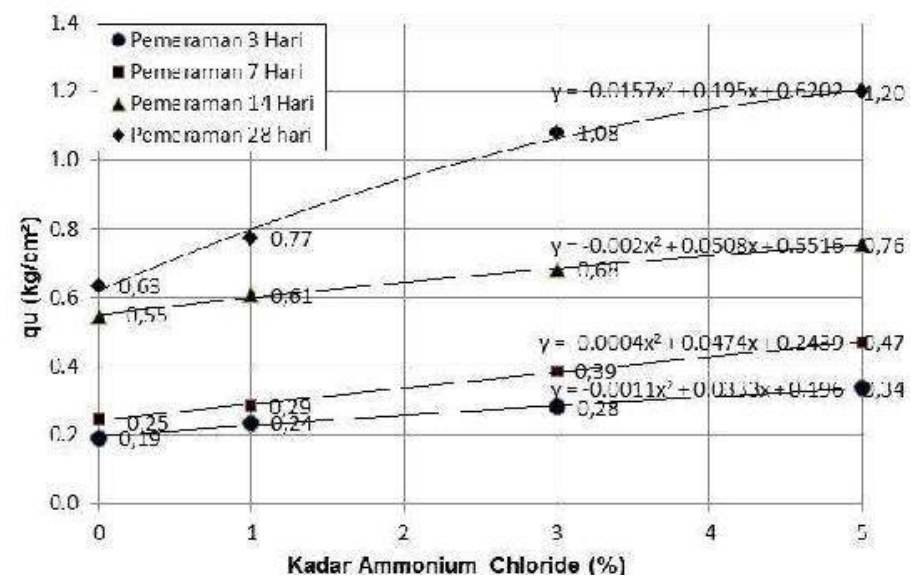

Gambar 4.3. Grafik Hubungan Nilai qu dan Variasi Kadar Ammonium Chloride

Untuk hubungan Nilai qu dan waktu pemeraman dapat dilihat pada Gambar 4.4 sebagai berikut.

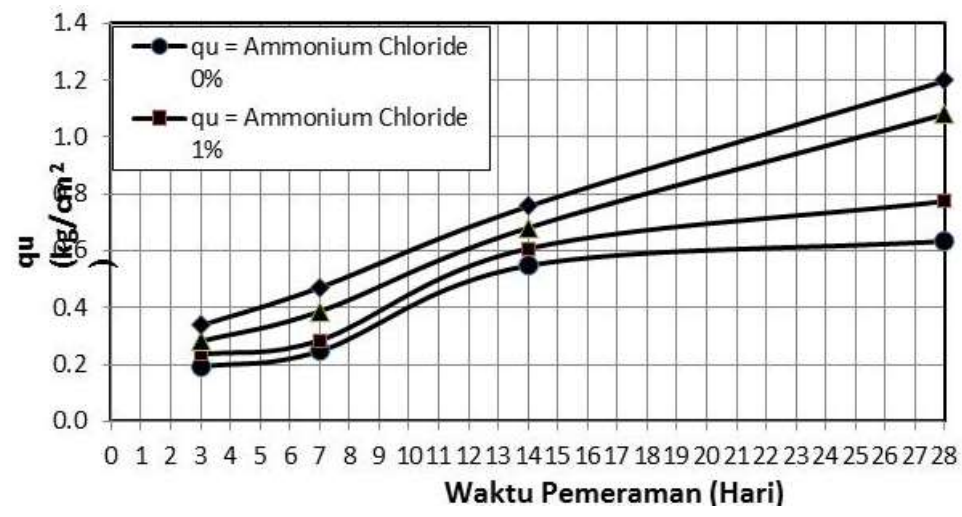

Gambar 4.4. Grafik Hubungan Nilai qu dan Waktu Pemeraman

Dari Gambar grafik 4.3. dan 4.4. menunjukkan bahwa penambahan kadar persentase ammonium chloride dan lamannya waktu pemeraman (curing time) dapat meningkatkan kekuatan tanah, hal ini terlihat bahwa perubahan pada tiap-tiap persentase kadar ammonium chloride dan lamanya waktu pemeraman (curing time) memberi nilai kekuatan (qu) yang cenderung meningkat. Pengaruhnya kekuatan maksimum berada pada kadar persentae ammonium chloride $5 \%$ antara waktu 3, 7, 14, dan 
28 hari yang signifikan. Hasil pengujian qu terhadap waktu pemeraman dengan variasi kadar ammonium chloride menunjukkan bahwa nilai ratarata tertinggi $\mathrm{qu}=1,20 \mathrm{~cm}^{2} / \mathrm{kg}$, (konsistensi kaku) terjadi pada variasi kadar persentase ammonium chloride $5 \%$ dengan waktu curing 28 hari. Sehingga dari hasil pengujian kuat tekan bebas diperoleh perilaku-perilaku berupa perubahan menyangkut sifat-sifat mekanis tanah setelah distabilisasi dengan variasi kadar Ammonium Chloride terhadap waktu pemeraman.

\subsection{Water Content Unconfined Compression Strenght (UCS) Test}

Nilai kadar air (Water Content) setiap sampel UCS untuk masingmasing komposisi campuran tanah dengan ammonium chloride dapat dilihat pada Tabel 4.4. Nilai water content ini merupakan nilai rata-rata dari pengujian 2 sampel yang diambil untuk setiap komposisi campuran.

Tabel 4.4 Water Content UCS Test

\begin{tabular}{|c|c|c|c|c|}
\hline \multirow{2}{*}{$\begin{array}{c}\text { Curing } \\
\text { (hari) }\end{array}$} & \multicolumn{4}{|c|}{ Water Content Rata-Rata ( \% ) } \\
\cline { 2 - 5 } & Tanah + AC 0\% & $\begin{array}{c}\text { Tanah + AC } \\
1 \%\end{array}$ & $\begin{array}{c}\text { Tanah + AC } \\
3 \%\end{array}$ & $\begin{array}{c}\text { Tanah + AC } \\
5 \%\end{array}$ \\
\hline 3 & 51,61 & 46,98 & 36,22 & 33,32 \\
\hline 7 & 53,94 & 45,66 & 36,43 & 31,84 \\
\hline 14 & 55,80 & 44,65 & 34,83 & 32,91 \\
\hline 28 & 55,33 & 46,16 & 34,46 & 34,06 \\
\hline
\end{tabular}

(Hasil Pemeriksaan Laboratorium)

Kemudian pada grafik 4.5. dapat dilihat nilai Hubungan Kadar Air dan Waktu Pemeraman.

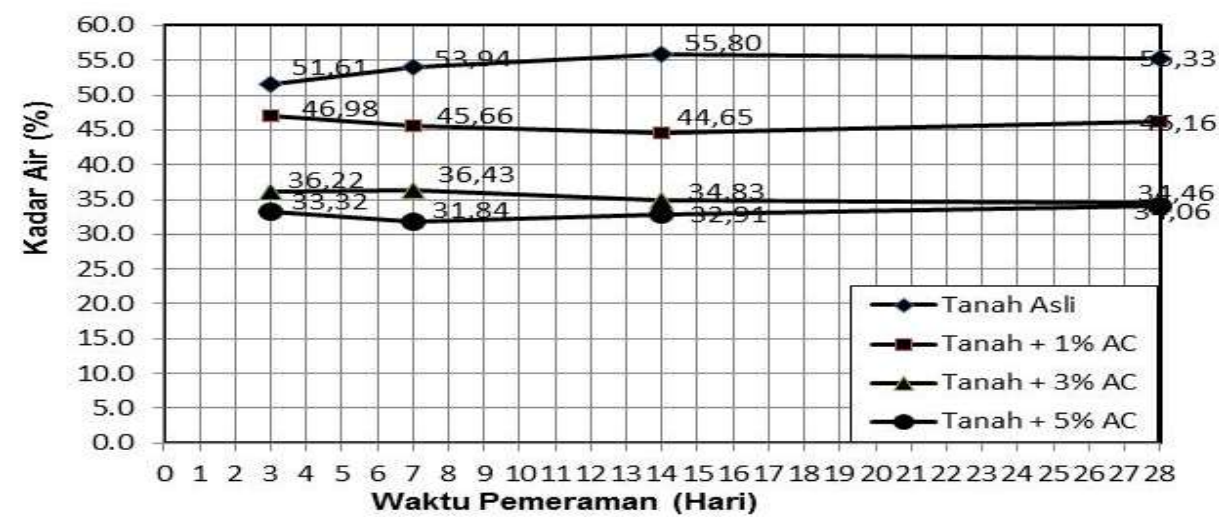

Gambar 4.5. Grafik Hubungan Kadar Air dan Waktu Pemeraman 
Gambar grafik 4.5. di atas memperlihatkan perubahan nilai kadar air terhadap waktu curing untuk semua komposisi campuran ammonium chloride. Hal ini menunjukkan bahwa nilai kadar air pada stabilisasi tanah lempung dengan menggunakan ammonium chloride semakin berkurang seiring penambahan persentasenya hingga $5 \%$.

\section{KESIMPULAN}

Berdasarkan analisis data yang dilakukan dalam penelitian ini, maka dapat ditarik beberapa kesimpulan sebagai berikut :

1. Pengujian Karakteristik fisis material tanah dalam penelitian berdasarkan uji analisa saringan dan uji hidrometer adalah 51,31\% lolos saringan 200 dengan kadar lempung 42,11\% lanau 9,2 \% dan pasir 48,69 \%. Untuk pengujian sifat indeks meliputi Kadar Air $=25,25$ $\%$, Gs $=2,545$, batas cair $=44,38 \%$, batas plastis $=25,36 \%$ dan Indeks plastis $=19,02 \%$. Pengujian klasifikasi USCS tanah di kategorikan (CL) Lempung berpasir dengan tingkat plastisitas sedang, sedangkan klasifikasi AASHTO dikategorikan sebagai tanah lempung dengan klasifikasi kelompok A - 7 -6.

2. Perilaku parameter kuat geser pada tanah lempung asli dan tanah lempung stabilisasi ammonium chloride dari hasil pengujian direct shear test menunjukkan terjadinya penurunan nilai sudut geser $(\varnothing)$ pada tanah lempung yang telah distabilisasi, nilai sudut geser minimum $\varnothing=14,20^{\circ}$ diperoleh pada variasi kadar persentase ammonium chloride $5 \%$ dengan waktu curing 28 hari. Sedangkan nilai sudut geser maksimum $\varnothing=34,29^{\circ}$ terjadi pada tanah lempung asli tanpa stabilisasi ammonium chloride dengan waktu curing 3 hari.

3. Perilaku parameter kuat tekan pada tanah lempung asli dan tanah lempung stabilisasi ammonium chloride dari hasil pengujian kuat tekan bebas (UCS) menunjukkan terjadinya peningkatan nilai kekuatan (qu) pada tanah lempung yang distabilisasi dengan ammonium chloride, nilai tertinggi qu $=1,20 \mathrm{~kg} / \mathrm{cm}^{2}$ dengan konsistensi kaku terjadi pada 
kadar persentase ammonium chloride $5 \%$ dengan waktu curing 28 hari.

\section{DAFTAR PUSTAKA}

1. Craig, R. F., 1989. Mekanika Tanah , Erlangga, Jakarta..

2. Das, Braja M,.Endah, Noor. Dan Mochtar, Indrasurya B. 1988. Mekanika Tanah (Prinsip-Prinsip Rekayasa Goeteknik)-Jilid I,. Erlangga, Jakarta.

3. Das, Braja M,.Endah, Noor. Dan Mochtar, Indrasurya B. 1988. Mekanika Tanah (Prinsip-Prinsip Rekayasa Goeteknik)-Jilid II. Erlangga, Jakarta.

4. Grim, R.E. 1992. Applied Clay Mineralogi, Mc Graw Hill Book Company, New York.

5. Hardyatmo, Hary Crhistiady. 2000. Mekanika Tanah 1 Edisi Kelima. UGM Press, Yogyakarta.

6. Hardyatmo, Hary Crhistiady. 2010. Stabilisasi Tanah Untuk Perkerasan Jalan. UGM Press, Yogyakarta.

7. Kh, Sunggono. 1984. Mekanika Tanah. Penerbit Nova, Bandung.

8. Nelson. D Jhon and Miller J Debora. 1991. Expansive Soil.

9. Wesley, L. D. 1997. Mekanika Tanah, Badan Penerbit Pekerjaan Umum, Jakarta 